UDC 622.765 .4

\title{
陽イオン捕収剤による磁硫鉄鉱の浮選*
}

\author{
正会員石原 \\ 透** \\ 正会員各 務 泰 道**
}

\section{Flotation of Pyrrhotite using Cationic Collector}

Tôru ISHIHARA and Yasumichi KAGAMI

Pyrrhotite is one of the minerals which have called attention in recent years. Generally, pyrrhotite is beneficiated as follows:

Feed $\longrightarrow$ Magnetic Separation $\longrightarrow$ Xanthate Flotation (or vice versa)

In this conventional flowsheet, the more floatable pyrrhotite is recovered by flotation with xanthate, while the less-floatable is recovered by magnetic separation. This is because the morefloatable pyrrhotite has weak magnetic property, while the less-floatable a stronger tendency.

In this study, the authors have succeeded in recovering the less-floatable pyhrrotite by flotation using 40g RADA per ton ore as a collector. Using RADA increases the floatability of pyrrhotite, which is hardly recovered by the conventional flotation. For instance, in the flotation of Kamaishi pyrrhotite, which showed a recovery of only $17 \%$ with $200 \mathrm{~g}$ potassium ethyl xanthate per ton of ore, a recovery of $86 \%$ is obtained with $40 \mathrm{~g}$ RADA per ton of ore treated.

As the results of this study, the process of magnetic separation may be eliminated in the beneficiation of pyrrhotite, so the flowsheet can be simplified as follows:

Feed $\longrightarrow$ Xanthate Flotation $\longrightarrow$ RADA Flotation

1. 緒

言

磁硫鉄鉣はわが国の重要なる硫黄および鉄資源の一つ であつて，焙焼法の発洼に伴い，急速に气の国内資源の 開発が進められている。しかしこれ学鉄鉣にくらべる とSの含有率が低いので売鉱上の不利は免れない。しか もとの選鉣については, 種々困難な問題が存在している。 磁硫鉄鉱については，今まで国内では，早瀨・原田の 「磁硫鉄鉣の特性」), 武中の「磁性抢よび電気的性 質」光，久保の「選鉱性」3) に関する研究等があり，外国 にも C. S. Chang らの「ザンセートを用いた磁硫鉄鉣 の浮馔性 出) 関する研究等が市る。

乙かし磁硫鉄鉱は，先の分子式 $\mathrm{Fe}_{n} S_{n+1}$ が示すよう そその諸性質が $n$ の值によつて変化主るので, 他の鉣物 のように性質がー定でなく，あたかも2 種またはそれ以 上の鉣物の混合物の上万な性質を示吉特色が認められ る。したがって，その選鉱も多くの困難る伴い，研究の 上飞も未解決の部分がまだ多く残されている。

筆者等は資源技術試験所に出いてここ数年磁硫鉄鈗の 選鉱に関する研究を続けているが，現在磁硫鉄鉣の選鈗 に採用されている磁選, 浮選の併用方式を, RADA

* 勋和33年度日本釷業会秋季大会にて講演

** 工業技術院 資源技術試験所 第 2 部 研究員
(Rosin Amine D Acetate) とザンセートを傎用した浮 選一本の操業方式に，改善する可能性沉いて研究した 結果，ある程度の成果を得たので，ここ発表する。

\section{2. 供試鉱石の性質}

供試鉱石には当研究室で集めた約 20 種の鉣石中, 性質 の異なる, 赤金鉣, 柵原鉣, 釡石鉣の 3 種を主として使 用した。鉣石の性質の扮拈よその判定には磁着量をるつ てレ, これに磁気分析を併用した。3 鉣石の化学成分, その他は第 1 表の通りである。

な括，顕微鏡試験によれば，各釷石とも少量の黄銅 鉱, 閃亚鉛鉣を含点。

X線回折法により，磁硫鉄鉱の $43^{\circ}(2 \theta)$ 付近の最強 ラインで 3 鉣石を比較検討したところ, 赤金鉱では回折 線のピークの先端に分裂が認められないのに反て, 柵 原, 釜石両鉣石に㧤いては分裂が認められ，とくに栅原 鉱に㧤いてそれが著しいことがわからた。これ泩磁硫鉄

第1表 供試鉣石の性質

\begin{tabular}{|c|c|c|c|c|c|c|c|c|}
\hline & & & \multicolumn{2}{|c|}{ 化 } & 分 & $(\%)$ & & \multirow{2}{*}{ 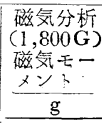 } \\
\hline & & & $\mathrm{Fe}$ & $\mathrm{S}$ & $\mathrm{Cu}$ & $\mathrm{SiO}_{2}$ & $\mathrm{Zn}$ & \\
\hline $\begin{array}{l}\text { 赤 } \\
\text { 釡 } \\
\text { 柵 }\end{array}$ & $\begin{array}{l}\text { 金 } \\
\text { 原 }\end{array}$ & $\begin{array}{l}\text { 鉣 } \\
\text { 鉱 } \\
\text { 鉱 }\end{array}$ & $\begin{array}{l}54.9 \\
52.5 \\
51.9\end{array}$ & $\begin{array}{l}41.5 \\
39.0 \\
42.5\end{array}$ & $\begin{array}{r}0.3 \\
0.8 \\
\text { tr }\end{array}$ & $\begin{array}{l}3.0 \\
8.2 \\
5.9\end{array}$ & $\begin{array}{r}0.2 \\
0.5 \\
\mathbf{t r}\end{array}$ & $\begin{array}{l}1.9 \\
3.2 \\
5.5\end{array}$ \\
\hline
\end{tabular}


鉣の結晶格子中の $\mathrm{Fe}$ 原子の格子欠損によるもので5), それが結晶内部構造に影響を拈よぽし，その対称性を低 下させ磁性増大の原因になつたものと考えられている。 これらのX線回折線の解析結果から, 供試鉣石は, 刪原 鉱，釜石鉱，赤金鉱の順に磁性が弱くなることが予想さ れるが，これは前記磁気分析の結果とも一致する。

鉣石の使用汇当つては, 炎の酸化について子つとも注 意しなければならないが，浮選試験て怙いては，一28〜 +100 mesh の粒度で広口瓶に貯蔵し, その試験直前に -200mesh $83 \%$ に乾式粉䂶をしたものを使用した。

\section{RADA による基礎試験}

\section{$3 \cdot 1$ 陰イオン捕收剤（ザンセート）と陽イオン捕收剤} (アミン)による浮選成績の比較

両種捕収剤による磁鉄鉱の浮選性を比較するために， 陰イオン捕収剤として Dow の KEX (Z-3) 50〜800g/t を，陽イオン捕収剤゙として Hercules の RADA 50〜 $800 \mathrm{~g} / \mathrm{t}$ をそれぞれ使用し，拈のおのに対し $\mathrm{CuSO}_{4}$ 0 $2,000 \mathrm{~g} / \mathrm{t}$ を併用して予備的な浮選試験を行つた。条件時 間 1.5 分，採取時間 3 分とした場合，得られた精鉱の重 量\%をグラフにプロットして等重量\%曲線を画くと，第 1 図のようになる。図中の数字は精鉣の重量\%を示す。

この図から一般に RADA 使用の場合の方が精鉣量が 多いことが判るが，特に 3 鉱石の浮遊性について検討す れば, まずKEX 使用の（a ）図では, 斜線部面積 (12.5 \%より大きな部分）で比較すると，赤金鉱，梱原鉱，釜 石鉣の順にその面積が小さくなり，一方 RADA 使用の (b)図では，その順に斜線部面積が大きくなる。このこ とはKEX で浮き難い鉱石には RADA が有効であり， また RADA で浮き難い鉣石には KEX が有効であるこ とを示している。

\section{$3 \cdot 2$ 接触角の測定}

3 鉣石を約 $1 \mathrm{~cm}^{3}$ の立方体に切断し，カーボランダム 粉で丁寧に㭬䇾し，パフにて仕上げた光沢面について， 水中気泡法によつて接触角を測定した。

恋ず鉣石をよく水洗し，D．W．McGlaskan 等の方 法昼火上る清浄性試験を行つた後，1分間 KEX または RADA の $1 \%$ 水溶液に浸し，とれから軽く蒸溜水で洗 つて, 光源と暗箱との中間にある蒸溜水セル中に懸垂す る。つぎに注射釬で気泡を鉱石片に付着させ，顕微鏡 （約20倍）を通してその像を暗箱のクモリガラスに投影 する。投影された気泡像について，その直径 $D$ と，鉱物 と泡との接触面の長さ $d$ を測定し, 接触角 $\theta$ を $\sin \theta=$ $\frac{d}{D}$ から匴した。算の結果, KEX に浸した場合は赤金 鈗 $\left(71^{\circ}\right)$, 相原鉣 $\left(59^{\circ}\right)$, 釜石鉱 $\left(46^{\circ}\right)$ の順に $\theta$ が小

\footnotetext{
* ACG の 2026 も使用したが RADA 伍ど良い成績でなかつたので
} ここでは省略する。
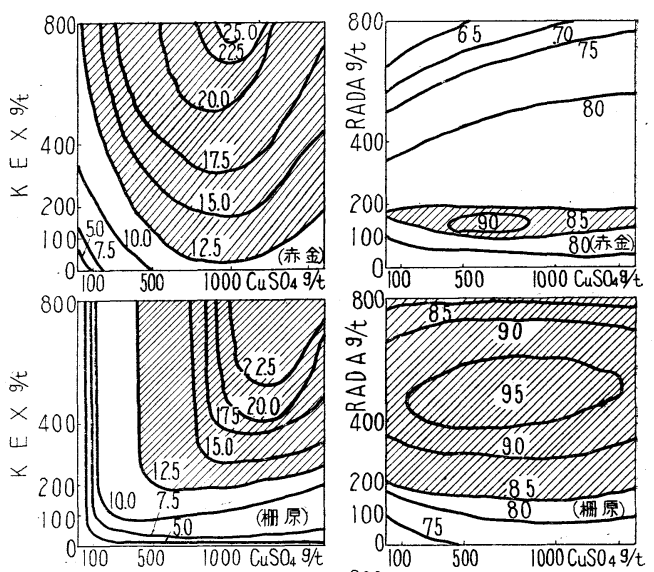

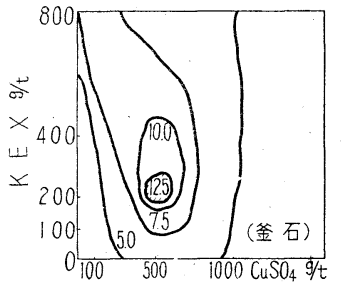

(a) KEX 使用

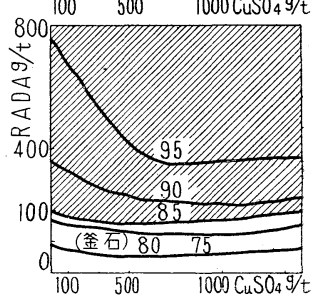

(b) RADA 使用
第1図 $\mathrm{KEX}, \mathrm{RADA}$ 使用 $\left(\mathrm{CuSO}_{4}\right.$ 併用) の時の 3 鉱石の浮遊性

さくなり, RADA では赤金鉱 $\left(48^{\circ}\right)$, 相原鉱 $\left(66^{\circ}\right)$, 釜石鉣 $\left(72^{\circ}\right)$ の順に $\theta$ が大きくなることが確かめられ た。このことは $3 \cdot 1$ の浮遊性の関係と一致する。

\subsection{RADA 浮選による浮遊性と磁性との関係}

磁硫鉄鉿の浮遊性と磁性の関倸については, 今まで種 々の研究1)がなされて打り, 陰イオン捕収刜使用(また は自然浮遊度）の場合には, S 原子率 $52.8 \%$ ( $\mathrm{Fe}$ 品位 60.8\%) のものが一番浮遊し難く, から磁着しやすいこ とが確認されている。しかるにRADA を使用する浮選 の場合には，これが全く逆になり磁着し易いものがもつ とも浮遊しやすい結果になる。この事は前述 3.1 の KEX とRADA との比較試験（第1図）で，3 鈗石の浮遊性 の順位が逆になつたことからも推測出来るが，ここでは さらにつぎの実験によりこの事実を確認した。

まず粒度 $-100 \sim+150 \mathrm{mesh}$ の赤金鉱を, 対極式磁選 機にて $800 ， 2,000 ， 5,000 ， 9,000$ 各ガウスにて磁選し, 磁性の異なる 4 つのグループに分ける。つぎにその各産 物党改良型 Hallimond 式微量用浮選機》で, RADA 約. $20 \mathrm{~g} / \mathrm{t}$ 使用して浮選を行つた。その場合の浮選時間と浮 遊量の関僁は第 2 四に示すような結果となつた。この困 から明らかなように, RADA 使用の場合は, 磁性の強 いものが浮遊し易い傾向にあることが認められる。

第3 図は KEX (50g/t 4 回添加), 末たは RADA (10 $\mathrm{g} / \mathrm{t}$ 3〜4回添加）にて浮選して得られた各精鉣を対極式 


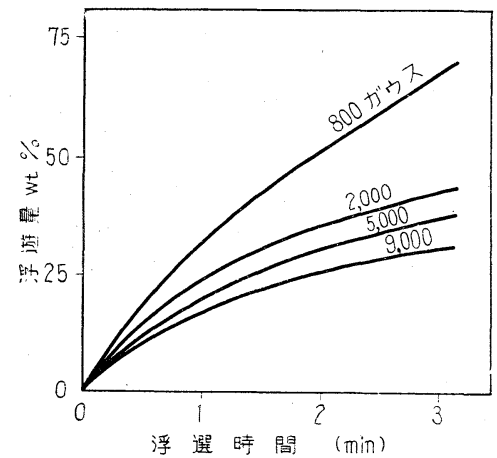

第 2 図

RADA 使用 に打ける各種 磁選産物の浮 遊性
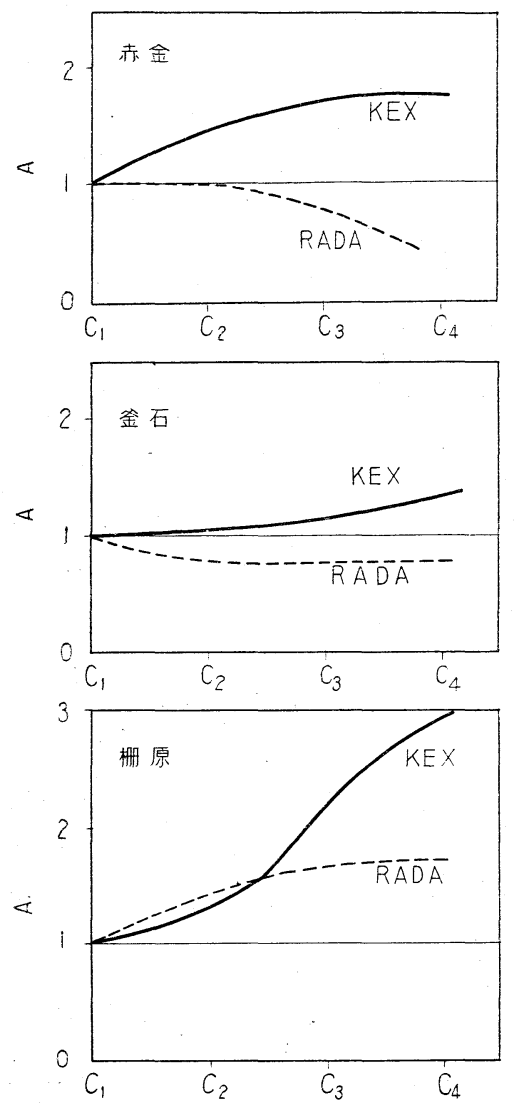

第 3 図 各浮選精鉱の 磁性比較 $A: \frac{C_{n} \mathrm{Wt} \%}{C_{1} \mathrm{Wt} \%}$

磁選機で 800 ガウスにて磁選し，その浮選第 1 精鉱の磁 着重量\%をもつて第 2 精鉱以下の磁着重量\%を割つた值 (A) で浮遊性と磁性との関係を比較したものである。 図中 $\mathrm{KEX}$ を使つた場合 (実線) は $\mathrm{C}_{1} \sim \mathrm{C}_{4}$ になるにし たがい（A）の值が増加し，浮遊性の低下にともない磁 着重量\%が多くなることを示しているが，RADA を使 つた場合 (破線) は，柵原鉣以外は $\mathrm{C}_{1} \sim \mathrm{C}_{4}$ になるにし たがい（A）の值が減少し，その磁着重量\%が少なくな ることを示している。すなわちこのことから浮選に RADA を使用すると，800 ガウスで磁着するような磁 性の強い銗粒が優先的に浮遊することがわかる。

\section{KEX と RADA の併用による浮選試験}

\section{4・1 KEX 単独使用による浮選試験}

比較のために上記 3 鉣石に, KEX のみ $(59 \mathrm{~g} / \mathrm{t} \times 4$ 回 $)$ を使用し，MS $50 \mathrm{~g}$ 浮選機を用い， $\mathrm{C}_{1} \sim \mathrm{C}_{4}$ までの精釷 を採取した。その結果は第 2 表 a)に示すように赤金鉣， 柵原鉱は浮遊しやすく，釜石鉣は浮遊し難かつた。

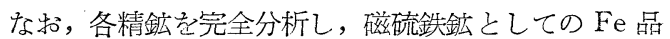
位を計算し，それと浮遊性との関係を調べて見ると第 4 図のようになる。これによると Fe 品位 59〜60\%の所 が，KEX 使用では一番浮遊しにくい事がわかる。そし てこの点は，な今まで述べたことから RADAを使つ た場合にはもつとも浮きやすい点であると考光られるの で, 実際上は KEX と RADA との併用が有効であるこ とが推測される。

\section{$4 \cdot 2$ 釜石鉱の KEX と， RADA の併用による浮選}

同様に MS $50 \mathrm{~g}$ 浮選機を使用し, つぎのょうなフロ ーシートと条件により試験を実施した。

条件: $\mathrm{KEX} 30 \mathrm{~g} / \mathrm{t}\left(\mathrm{C}_{1}\right)$, RADA 各々 $10 \mathrm{~g} / \mathrm{t}\left(\mathrm{C}_{2} \sim \mathrm{C}_{i}\right)$, パイン油各回 $20 \mathrm{~g} / \mathrm{t}$, 条件時間各回 1.5 分, 精鉣 採取時間各回 3 分

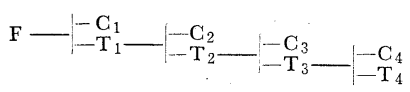

釜石鉙は 4.1 で述べた KEX 単独使用の場合には，も つとも浮遊しにくい鉱石であつたが，この試験では第 5 図にみられるように $\mathrm{Fe}$ の積算寒収率約 5 倍の向上を 見ている。しかも精鉣の Fe 品位は KEX 使用時にくら ベると，数\%の向上をみせ，56\% Fe である。

RADA 使用の場合一番眯念されるのは, 精鉣中への $\mathrm{SiO}_{2}$ 分の混入であるが，1 回の RADA 使用量 $10 \mathrm{~g} / \mathrm{t}$ 程

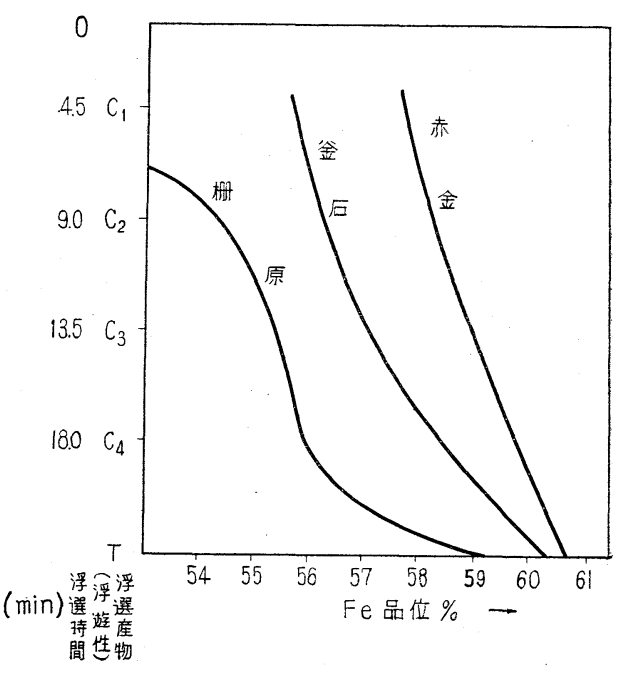

第 4 図磁硫鉄鉱の $\mathrm{Fe}$ 品位々浮遊性との 関係 (KEX 使用) 


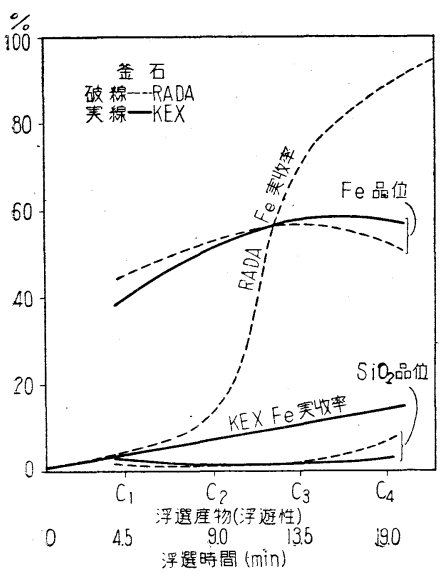

第 5 図 浮選成績（釜石鉱）

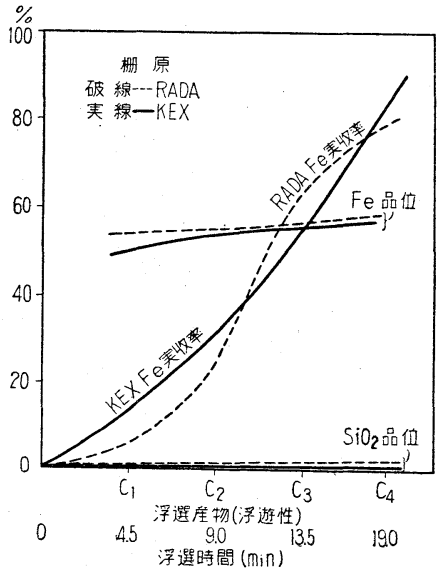

第 6 図 浮選成績（栅原鉱）

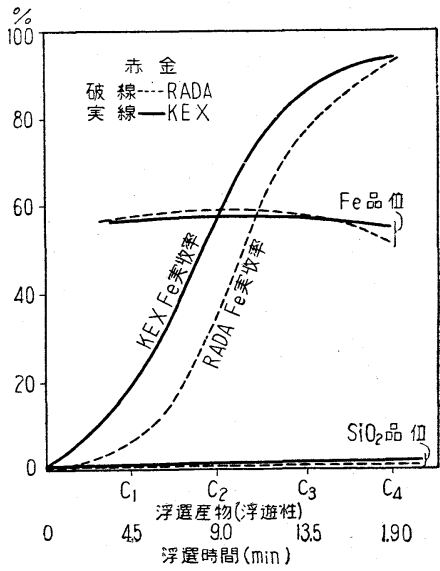

第 7 図 浮選成績（赤金鉱）
度は，珪酸鉱物を浮遊させるには不足なので，KEX の 場合と大差ない。すなわち釜石鉱について RADA を使 用した場合の $\mathrm{C}_{1} \sim \mathrm{C}_{4}$ の積算 $\mathrm{SiO}_{2}$ 品位は $4.8 \%(\mathrm{Fe}$ 実 収率 $85 \%$ ) で，KEX 単独使用の場合の $3.8 \%$ ( Fe 実収 率17\%) と比べて大差ない。な报その時の尾鈗の $\mathrm{SiO}_{2}$

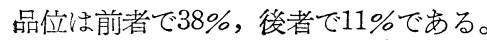

\section{3 赤金鉱，梅原鉱の KEX と RADA の併用によ る浮選}

この 2 鉣石は KEX のみでかなり良い成績を示した が,RADA との併用によつても同じ程度あるいはやや良 好な成績を示した。その結果を第 6 図と第 7 四に示す。

以上の浮選試験の成績 $\left(\mathrm{C}_{1} \sim \mathrm{C}_{4}\right.$ 積算)をまとめると, 第 2 表の通りである。この表から判るように，精鉣の $\mathrm{Fe}$ 品位, Fe 実収率ともに RADA 併用の場合は KEX 単独の時にくらべて成績が良く，とくに KEX で浮き難 い鉣石に対して良い結果をあたえることが認められる。

\section{5. 結}

言

現在，磁硫鉄鉱の選鉱には，通常まず磁選して精鉣を 採取し，それで磁着し得ない磁硫鉄鉣について，浮選を 適用してこれを回収しているが，その操業には相当困難 を伴い，実収率が低いところもある。ここに筆者等は陽 イオン捕収剤 (RADA) による磁硫鉄鉣の浮選について 研究し，つぎのような結果を得た。

1） $\mathrm{RADA}$ を $30 \mathrm{~g} / \mathrm{t}$ 程度使用することにより，磁硫 鉄鉱を浮選回収することに成功した。これはとくに，ザ

第 2 表 浮 選 成 績 表

\begin{tabular}{|c|c|c|c|c|c|c|}
\hline \multirow[b]{2}{*}{ 条 } & \multicolumn{2}{|c|}{ 赤 金 鉱 } & \multicolumn{2}{|c|}{ 棚 原 鉱 } & \multicolumn{2}{|c|}{ 釜 石 鉱 } \\
\hline & $\begin{array}{l}\mathrm{Fe} \\
\text { 品位 } \\
(\%)\end{array}$ & $\begin{array}{c}\mathrm{Fe} \\
\text { 実收率 } \\
(\%)\end{array}$ & $\begin{array}{l}\mathrm{Fe} \\
\text { 品位 } \\
(\%)\end{array}$ & $\begin{array}{c}\mathrm{Fe} \\
\text { 実収率 } \\
(\%)\end{array}$ & $\begin{array}{l}\mathrm{Fe} \\
\text { 品位 } \\
(\%)\end{array}$ & $\begin{array}{c}\mathrm{Fe} \\
\text { 実收率 } \\
(\%)\end{array}$ \\
\hline \multirow{2}{*}{$\begin{array}{l}\text { a) } \operatorname{KEX~} 200 \mathrm{~g} / \mathrm{t} \\
\text { b) } \operatorname{RADA~} 30 \mathrm{~g} / \mathrm{t} \\
\operatorname{KEX~} 30 / \mathrm{g}\end{array}$} & 57 & 92 & 54 & 81 & 52 & 17 \\
\hline & 58 & 94 & 56 & 88 & 56 & 86 \\
\hline
\end{tabular}

ンセートでは浮選しにくい型の鉱石に対し有効で，一例 をあげると，釜石鉣の場合 $\mathrm{KEX}$ によ Fe 実収率 $17 \%$ のものを約 5 倍の $86 \%$ にまで高め得た。

2) 磁束密度を変化させて採取した各種磁選泩物を RADA で浮選した結果, 磁性の強いもの流ど浮遊し.官 すいことが確認された。これはザンセートが磁性の強い ものを浮遊させにくいのと全く逆の結果である。RADA を使えば現在行われている，磁選とザンセート浮選の併 用を, ザンセート浮選-D-RADA 浮選の浮選一本に真 きかえることが可能と考えられる。

本研究に際し種々御支援をた京るつた資源技術試験所 第 2 部の木内部長, 山本課長, 富田技官に感謝し, とく に磁気分析の労をたまわつた東京大学物理学教室の関沢 尚氏，X線回折試験を担当された当所の小倉技官に対 し，厚く御礼申し上げる。

\section{参 考 文 献}

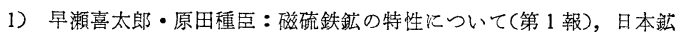
業会誌，67巻，754号，昭和26年 3 月，94頁 101頁。同上（第 2 報), 日本鈗業会誌, 68 巻, 769 号, 昭和 27 年 7 月, $295 \sim 300$ 頁。同 上 (第 3 報), 日本釷業会誌, 68巻, 773号, 昭和27年11月, 513 517 頁。同上 (第 4 報)，日本釷業会誌，69巻，778号，昭和 28 年 4 月, 113 117頁

2）武中俊三：磁硫鉄鉱の磁性と釷床について，71巻，808号，昭和 30 年10月, 629 632頁

同上: 71 巻，809号，昭和 30 年 10 月，671 677頁

3）久保秀正：磁硫鉄鈗処理方法の改善，日本釷業会誌，73巻，833号， 昭和32年11月, 801 809頁

4) C. S. Chang • S. R. B. Cooke •I. Iwasaki: "Flotation Characteristics of Pyrrhotite with Xanthates", Min. Eng., Feb. 1954 pp. 209 217.

5）早瀬喜太郎・原田種臣：X線ディフラクトメーター飞よる磁硫鉄釿 の化学組成一組晶構造一磁性の関係の研究, 日本鉱業会誌, 73 巻, 830 号, 昭和 32 年 8 月, 486 492頁

6) Donald W. McGlashan and Kenneth N. Mcleod: "Improved Contact Angle Apparatus for Flotation Research", Min. Eng., March, 1956. pp. 310 314.

7) D. W. Fuerstenau P. H. Metzger - G. D. Seele: How to this Modifid Hallimond Tube for Better Flotation Test= ing, E. M. J. March, 1957. pp. 93 95. 